\title{
Characteristic of different level of fermented concentrate in the rumen metabolism based on in vitro
}

\author{
N.F. Sari*, R. Ridwan, Rohmatussolihat, R. Fidriyanto, W.D. Astuti and \\ Y. Widyastuti \\ Research Center for Biotechnology, Indonesian Institute of Sciences \\ Jl. Raya Bogor km 46, Cibinong, Bogor, West Java, Indonesia 16911 \\ *Corresponding E-mail : nurulfitrisari@gmail.com
}

Received January 09, 2018; Accepted March 27, 2018

\begin{abstract}
ABSTRAK
Kecernaan merupakan gambaran dari kemampuan bahan pakan yang dapat digunakan oleh ternak. Semakin tinggi suatu kecernaan, semakin banyak bahan pakan yang dapat dicerna di dalam saluran pencernaan. Penelitian ini bertujuan untuk mendapatkan proporsi penggunaan konsentrat terfermentasi pada fermentasi rumen secara in vitro. Pakan yang digunakan terdiri dari tujuh perlakuan sebagai berikut : P1 (20\% Pennisetum purpureum : 80\% konsentrat), P2 (30\% P.purpureum : 70\% konsentrat), P3 (40\% P.purpureum : 60\% konsentrat), P4 (50\% P.purpureum : 50\% konsentrat), P5 (20\% konsentrat: 80\% P.purpureum), P6 (30\% konsentrat: 70\% P.purpureum) dan P7 (40\% konsentrat : 60\% P.purpureum). Kecernaan bahan kering $(\mathrm{KcBK})$ dan kecernaan bahan organik $(\mathrm{KcBO})$ dilakukan menggunakan metode Theodorou. Produksi gas diukur pada saat sampel diinkubasi pada suhu $39^{\circ} \mathrm{C}$ di dalam penangas air pada jam ke- 2, 4, 6, 8,10, 12, 24, dan 48. Sebanyak 0,75 g formulasi pakan dicampurkan dengan $75 \mathrm{~mL}$ cairan buffer rumen. Cairan rumen diambil dari 3 sapi fistula sebelum pemberian pakan di pagi hari. Rancangan acak lengkap dengan tiga kali ulangan digunakan. Produksi dan kinetika gas diestimasi menggunakan model Orskov. Hasil penelitian menunjukkan bahwa pada perlakuan P2 dan P3 menunjukkan kecernaan tertinggi dibanding perlakuan lainnya dengan KcBK masing-masing sebesar $71,63 \% ; 71,06 \%$ dan KcBO masing-masing sebesar 76,42\% ; 71.65\%. Disimpulkan bahwa perlakuan P2 dan P3 dapat digunakan sebagai pakan untuk sapi potong.

Kata kunci : sapi; fermentasi rumen, konsentrat terfermentasi, kecernaan, in vitro.
\end{abstract}

\begin{abstract}
Digestibility is a description of the ability of feed material that can be utilized by livestock. Higher digestibility of feed material means the total amount of feed content that can be digested in the digestive tract. This study aimed to obtain the proportion of the use of fermentation concentrate in rumen fermentation based on in vitro. The feed used consisted of 7 treatments as follows P1 (20\% Pennisetum purpureum: 80\% concentrate), P2 (30\% P.purpureum : $70 \%$ concentrate), P3 (40\% P.purpureum : 60\% concentrate), P4 (50\% P.purpureum : 50\% concentrate), P5 (20\% concentrate: 80\% P.purpureum), P6 (30\% concentrate: 70\% P.purpureum) and P7 (40\% concentrate: 60\% P.purpureum). Dry matter digestibility (DMD) and organic matter digestibility (OMD) were done using Theodorou method. Gas production was measured when the samples were incubated at $39^{\circ} \mathrm{C}$ in the waterbath incubator at hours $2,4,6,8,10,12,24$, and 48 . Approximately $0.75 \mathrm{~g}$ of feed formulation was mixed with $75 \mathrm{~mL}$ of rumen fluid buffer. The rumen fluid is taken from 3 fistulated cattles prior to morning feeding. A complete randomized design with three replicates was used. Asymptotic gas production and
\end{abstract}


kinetics were estimated by the Orskov's model. The results of this study showed that P2 and P3 treatment showed the best digestibility among others treatment with $71.63 \% ; 71.06 \%$ of DMD and $76.42 \% ; 71.65 \%$ of OMD. In conclusion, $\mathrm{P} 2$ and P3 treatment can be used as feed for beef cattle.

Keywords: cattle, rumen fermentation, femented concentrate, digestibility, in vitro

\section{INTRODUCTION}

The improper storage technique of concentrate for a long time period and in humid conditions can trigger contamination of concentrate by microorganisms causing rancid odor (Canibe and Jensen, 2012). This may affect the nutritional quality of the concentrate as well as the palatability of feed. Therefore, to reduce the contamination of the concentrate by microorganisms, it can be processed through fermentation. The fermentation technique can inhibit the growth of microbial pathogens and also can improve the quality of nutrient concentrates (Lee and Mau., 2008; Cao et al., 2012). In addition, the process of fermentation increases the vitamins, enzymes, and growth factors of fermented products ( $\mathrm{Ng}$ et al., 2011; Dei et al., 2008).

The use of microbial inoculants to ferment concentrate have been commonly studied in livestock, especially in pigs and poultry. Nevertheless, there have been limited studies of the use of microbial inoculant to ferment concentrate in ruminant. In addition, there have been few studies about the use of lactic acid bacteria in fermented concentrate could increase the availability of phosphorus in cereal baseddiets, able to reduce IP6 (Reale et al., 2004 ). The effects of fermentation on feed depend on the activity and type of microbial used (Niba et al., 2009).

Many researchers reported the beneficial of the use of microbial inoculant in fermented concentrate. As reported by Niba et al (2008) that the use of lactic acid bacteria can increase the concentration of lactic acid. Ahmed et al (2016) also reported that fermented feed contains large number of Lactobacilli with high concentrations of lactic acid and other volatile fatty acids and has a low pH. Moreover, Kobashi et al (2008) reported that the proportion of chlortetracyclineresistant Escherichia coli strains was significantly reduced in the gut of weaned piglets compared with dry feed. Fermented feed may provide more rich nutrition, better palatability, and increased digestibility so the needs of cattle protein could be met and could improve the performance of beef cattle (Niba et al., 2009; Humer et al., 2013). However, further research is needed to determine optimal proportion of fermented concentrate. The objective of this study was to characterize the effects of different level of fermented concentrate and elephant grass on the rumen fermentation in vitro.

\section{MATERIALS AND METHODS}

\section{Sample preparation}

Concentrate was made from the following formulation : $22 \%$ of rice bran, $5 \%$ of maize flour, $5 \%$ of coffee pulp, $10 \%$ of corn gluten feed, $6 \%$ of cassava flour waste, $9 \%$ of coconut meal, $18 \%$ of palm kernel cake, $18 \%$ of pollard brand, $6 \%$ of soy bean meal, and $1 \%$ of mineral mix. The formulation concentrate was fermented by adding $2 \%$ of $L$. plantarum $\left(2.5 \times 10^{6} \mathrm{cfu} / \mathrm{mL}\right)$ and kept for 24 hours incubation. Lactobacillus plantarum TSD-10 was from the laboratory of Applied Microbiology, Research Center for Biotechnology. Pennisetum purpureum were freshly collected from Agrostology Laboratory Field, Research Center for Biotechnology, LIPI. These materials were oven-dried at $60^{\circ} \mathrm{C}$ for $24 \mathrm{~h}$, milled using a grinder to pass a $1 \mathrm{~mm}$ sieve.

\section{Chemical and pH analysis}

Samples of P.purpureum and fermented concentrate were analyzed for dry matter (DM) and ash according to AOAC (2005). Crude protein (CP), crude fiber (CF), ether extract (EE) were determined followed the manufacture procedure of FOSS. The $\mathrm{NH}_{3}-\mathrm{N}$ concentration was determined by a Conway micro-diffusion method. Volatile Fatty Acids (VFA) were determined in centrifuged samples (1mL) by Gas Chromatography (GC) as described by Goering and Van Soest (1970). pH measurement of mix buffer rumen fluids were measured using $\mathrm{pH}$ meter (Jenway Model 3505, UK). Prior to the measurements, $\mathrm{pH}$ meter was calibrated by using $\mathrm{pH} 7$ buffer solution and it was prepared carefully as the manufactures instructions. All chemical composition analyses were conducted in triplicate. 
Table 1. Chemical Composition (g/kg DM)

\begin{tabular}{lccccc}
\hline \multicolumn{1}{c}{ Item $^{\mathrm{a}}$} & $(\%) \mathrm{DM}$ & $(\%) \mathrm{CP}$ & $(\%) \mathrm{CF}$ & (\%) EE & $\mathrm{pH}$ \\
\hline Pennisetum purpureum & 97.40 & 9.04 & 29.72 & 1.53 & \\
Concentrate & 89.37 & 13.70 & 21.14 & 1.85 & 6.24 \\
Fermented Concentrate & 89.96 & 14.82 & 18.13 & 1.70 & 4.47 \\
\hline
\end{tabular}

$\mathrm{DM}=$ dry matter; $\mathrm{CP}=$ crude protein; $\mathrm{CF}=$ crude fiber; $\mathrm{EE}=$ ether extract ; ${ }^{\mathrm{a}}$ Data are the means of three replicate analysis.

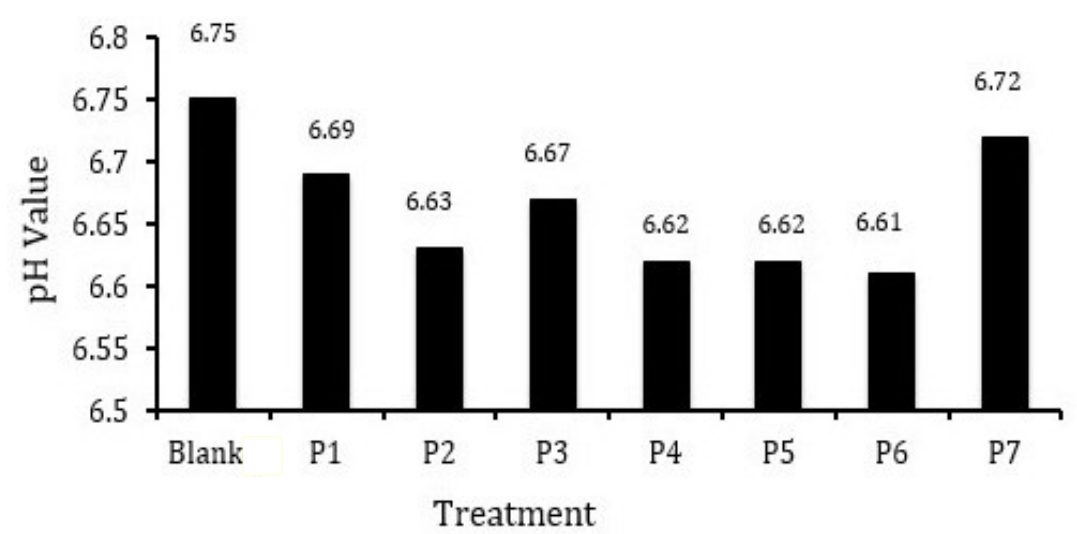

Figure 1. $\mathrm{pH}$ value of fermented concentrate. $\mathrm{P} 1=20 \%$ Pennisetum purpureum: $80 \%$ concentrate; $\mathrm{P} 2=$ 30\% P.purpureum: $70 \%$ concentrate ; P3 $=40 \%$ P.purpureum : $60 \%$ concentrate ; $\mathrm{P} 4=50 \%$ P.purpureum: $50 \%$ concentrate ; P5 $=20 \%$ concentrate: $80 \%$ P.purpureum; P6 $=30 \%$ concentrate: $70 \%$ P.purpureum ; $\mathrm{P} 7=40 \%$ concentrate: $60 \%$ P.purpureum

\section{In vitro Incubation and Gas Production}

Samples of P.purpureum and fermented concentrate were arranged and mixed according to the following experimental treatments (dry matter basis). These treatments were subjected to in vitro analysis according to Theodorou et al. (1994): P1 : $20 \%$ P. purpureum : $80 \%$ concentrate feeds P2 : $30 \%$ P. purpureum : $70 \%$ concentrate feeds P3 : $40 \%$ P. purpureum : $60 \%$ concentrate feeds P4 : $50 \%$ P. purpureum : $50 \%$ concentrate feeds P5 : $80 \%$ P. purpureum : $20 \%$ concentrate feeds P6 : $70 \%$ P. purpureum : $30 \%$ concentrate feeds P7 : 60\% P. purpureum : $40 \%$ concentrate feeds

Rumen contents were obtained from three fistulated cattles, then was mixed and strained through four layers of cheesecloth into an erlenmeyer flask with headspace. The use of the cattle in this experiment was approved No. $9879 / \mathrm{WK} / \mathrm{HK} / \mathrm{XI} / 2015$ by the Ethic Clearance Committee of Indonesian Institute of Sciences. Approximately $0.75 \mathrm{~g}$ of substrates were put inside the serum bottle glass and filled with 73
$\mathrm{mL}$ mixture of $24.33 \mathrm{~mL}$ rumen fluid and 48.67 $\mathrm{mL}$ of Mc'Dougall buffer $\left(\mathrm{NaHCO}_{3} 0.98 \mathrm{~g}\right.$, $\mathrm{Na}_{2} \mathrm{HPO}_{4} .7 \mathrm{H}_{2} \mathrm{O} 0.7 \mathrm{~g}, \mathrm{KCl} 0.057 \mathrm{~g}, \mathrm{NaCl} 0.0472$ g, $\mathrm{MgSO}_{4} .7 \mathrm{H}_{2} \mathrm{O} 0.012 \mathrm{~g}, \mathrm{CaCl} 0.004 \mathrm{~g}$, and $\mathrm{H}_{2} \mathrm{O}$ up to $100 \mathrm{~mL}$ ). Anaerobic condition in the bottles was achieved by filling $\mathrm{CO}_{2}$ gas until saturated. Serum bottles were sealed with butyl rubber stoppers and aluminum crimp seals shortly before starting the incubation. The bottles were placed in a water bath at $39^{\circ} \mathrm{C}$ for $48 \mathrm{~h}$. After $2,4,6,8,10$, 12,24 and $48 \mathrm{~h}$ of incubation, gas production from each serum bottle was vented and recorded by using disposable syringe.

In vitro gas production was analysed in seven different treatments of P1, P2, P3. P4, P5, $\mathrm{P} 6$, and $\mathrm{P} 7$ in three replicates. In addition, three blank (no sample; rumen fluid + buffer mixture) were used to calculate the total gas production. Gas production kinetics were estimated by following Ørskov method (Ørskov and McDonald, 1979). 
Table 2. Gas Production Kinetics during 48 Hours of Incubation

\begin{tabular}{ccrrrrrrc}
\hline \multirow{2}{*}{$\begin{array}{c}\text { Time } \\
(\mathrm{Hr})\end{array}$} & \multicolumn{7}{c}{ Treatment $(\mathrm{mL})$} \\
\cline { 2 - 9 } & Blank & \multicolumn{1}{c}{ P1 } & \multicolumn{1}{c}{ P2 } & \multicolumn{1}{c}{ P3 } & \multicolumn{1}{c}{ P4 } & \multicolumn{1}{c}{ P5 } & \multicolumn{1}{c}{ P6 } & P7 \\
\hline 2 & $0 \pm 0$ & $8.5 \pm 1.5^{\mathrm{ab}}$ & $5.2 \pm 2.3^{\mathrm{a}}$ & $6.2 \pm 3.6^{\mathrm{a}}$ & $8.8 \pm 2.85^{\mathrm{ab}}$ & $20.0 \pm 6.6^{\mathrm{c}}$ & $20.50 \pm 0.5^{\mathrm{c}}$ & $13.8 \pm 5.4^{\mathrm{bc}}$ \\
4 & $0 \pm 0$ & $18.7 \pm 2.8^{\mathrm{ab}}$ & $12.3 \pm 3.55^{\mathrm{a}}$ & $14.0 \pm 7.2^{\mathrm{a}}$ & $19.5 \pm 5.0^{\mathrm{ab}}$ & $37.3 \pm 10.3^{\mathrm{c}}$ & $38.2 \pm 0.8^{\mathrm{c}}$ & $28.3 \pm 9.8^{\mathrm{bc}}$ \\
6 & $1.2 \pm 1.0$ & $35.5 \pm 4.3^{\mathrm{ab}}$ & $22.3 \pm 3.9^{\mathrm{a}}$ & $25.3 \pm 12.0^{\mathrm{a}}$ & $34.6 \pm 7.3^{\mathrm{ab}}$ & $60.0 \pm 13.3^{\mathrm{c}}$ & $62.0 \pm 03.9^{\mathrm{c}}$ & $45.8 \pm 14.6^{\mathrm{bc}}$ \\
8 & $2.7 \pm 4.5$ & $53.5 \pm 3.8^{\mathrm{ab}}$ & $34.0 \pm 3.9^{\mathrm{a}}$ & $37.7 \pm 14.7^{\mathrm{a}}$ & $50.7 \pm 7.9^{\mathrm{ab}}$ & $78.5 \pm 14.5^{\mathrm{c}}$ & $79.8 \pm 4.0 \mathrm{c}$ & $61.7 \pm 16.4^{\mathrm{bc}}$ \\
10 & $7.3 \pm 6.8$ & $79.3 \pm 3.8^{\mathrm{c}}$ & $51.7 \pm 3.6^{\mathrm{a}}$ & $55.3 \pm 17.5^{\mathrm{ab}}$ & $74.2 \pm 865^{\mathrm{bc}}$ & $101.3 \pm 13.8^{\mathrm{d}}$ & $101.7 \pm 3.7^{\mathrm{d}}$ & $8.02 \pm 17.8^{\mathrm{cd}}$ \\
12 & $14.3 \pm 7.4$ & $95.3 \pm 2.8^{\mathrm{b}}$ & $65.7 \pm 3.3^{\mathrm{a}}$ & $70.0 \pm 17.7^{\mathrm{a}}$ & $90.8 \pm 8.8^{\mathrm{b}}$ & $117.7 \pm 14.4^{\mathrm{c}}$ & $118 \pm 3.9 \mathrm{c}$ & $97.8 \pm 18.8^{\mathrm{bc}}$ \\
24 & $27.5 \pm 6.1$ & $137.8 \pm 3.3^{\mathrm{b}}$ & $97.5 \pm 3.6^{\mathrm{a}}$ & $110.5 \pm 23.4^{\mathrm{a}}$ & $143.2 \pm 15.5^{\mathrm{b}}$ & $173.2 \pm 13.3^{\mathrm{c}}$ & $175.0 \pm 5.7^{\mathrm{c}}$ & $154.8 \pm 19.69^{\mathrm{bc}}$ \\
48 & $37.5 \pm 6.1$ & $165.0 \pm 3.8^{\mathrm{bc}}$ & $119.5 \pm 3.6^{\mathrm{a}}$ & $141.5 \pm 23.4^{\mathrm{ab}}$ & $175.7 \pm 15.9^{\mathrm{bc}}$ & $212.8 \pm 17.9^{\mathrm{e}}$ & $216.3 \pm 7.4^{\mathrm{e}}$ & $194.5 \pm 21.3^{\mathrm{de}}$ \\
\hline
\end{tabular}

$\mathrm{P} 1=20 \%$ Pennisetum purpureum: $80 \%$ concentrate; $\mathrm{P} 2=30 \%$ P.purpureum: $70 \%$ concentrate; $\mathrm{P} 3=40 \%$ P.purpureum : $60 \%$ concentrate; P4 $=50 \%$ P.purpureum: $50 \%$ concentrate; P5 $=20 \%$ concentrate: $80 \%$ P.purpureum; P6 $=30 \%$ concentrate: $70 \%$ P.purpureum; $\mathrm{P} 7=40 \%$ concentrate: $60 \%$ P.purpureum; a-e Different superscripts within the same column are significantly different at $\mathrm{P}<0.05$.

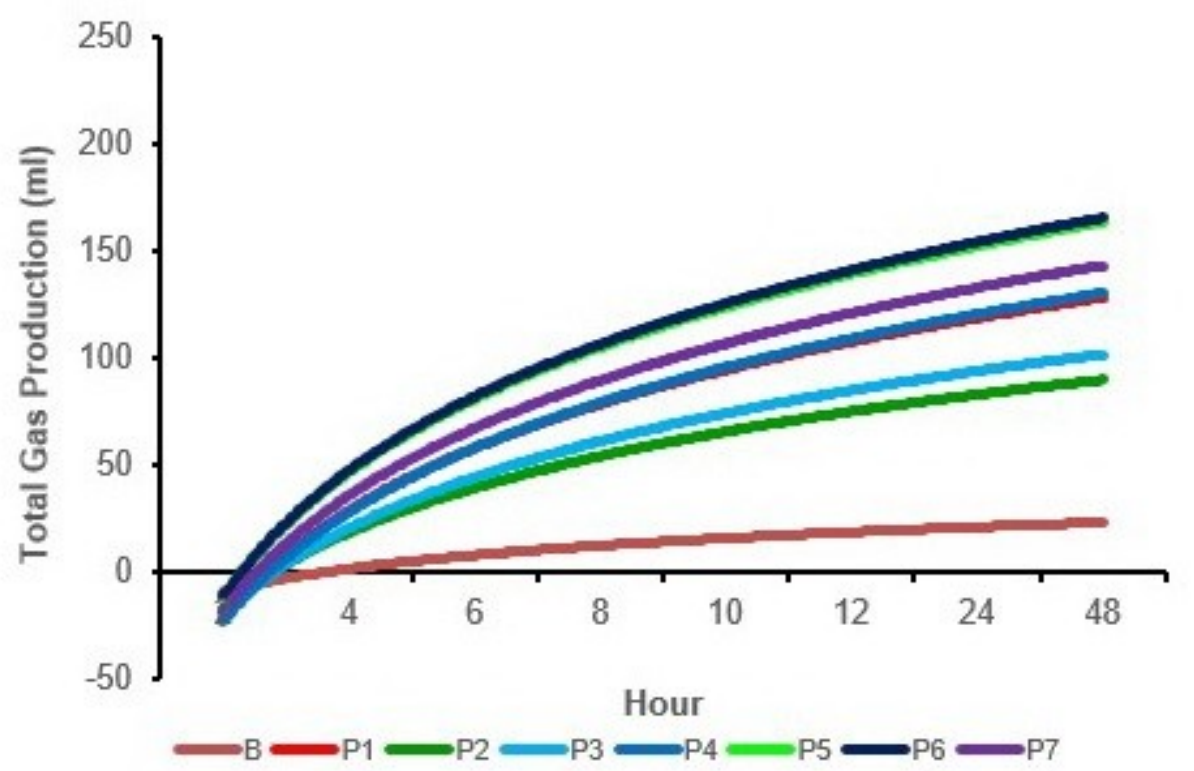

Figure 2. Total Gas Production during 48 Hours of Incubation. P1 $=20 \%$ Pennisetum purpureum: 80\% concentrate; $\mathrm{P} 2=30 \%$ P.purpureum: $70 \%$ concentrate; $\mathrm{P} 3=40 \%$ P.purpureum : $60 \%$ concentrate; $\mathrm{P} 4=$ 50\% P.purpureum: 50\% concentrate; P5 $=20 \%$ concentrate: $80 \%$ P.purpureum; P6 $=30 \%$ concentrate: $70 \%$ P.purpureum; $\mathrm{P} 7=40 \%$ concentrate: $60 \%$ P.purpureum

\section{Microbiology analysis}

Total lactic acid bacteria and rumen bacteria were counted as colony forming units (CFU) per $\mathrm{mL}$. The lactic acid bacteria were grown on MRS agar medium and counted by using total plate count (Cappucino, 2001), while the rumen bacteria on 98-5 agar medium were grown anaerobically by following the method of roll tube (Hungate, 1969). Incubation was done at $38^{\circ} \mathrm{C}$ for 3-4 days. Aliquots of fresh filtrate $(1 \mathrm{~mL})$ were added to $1 \mathrm{~mL}$ of protozoal staining solution (MFS solution, Ogimoto and Imai, 1987). Ciliate 


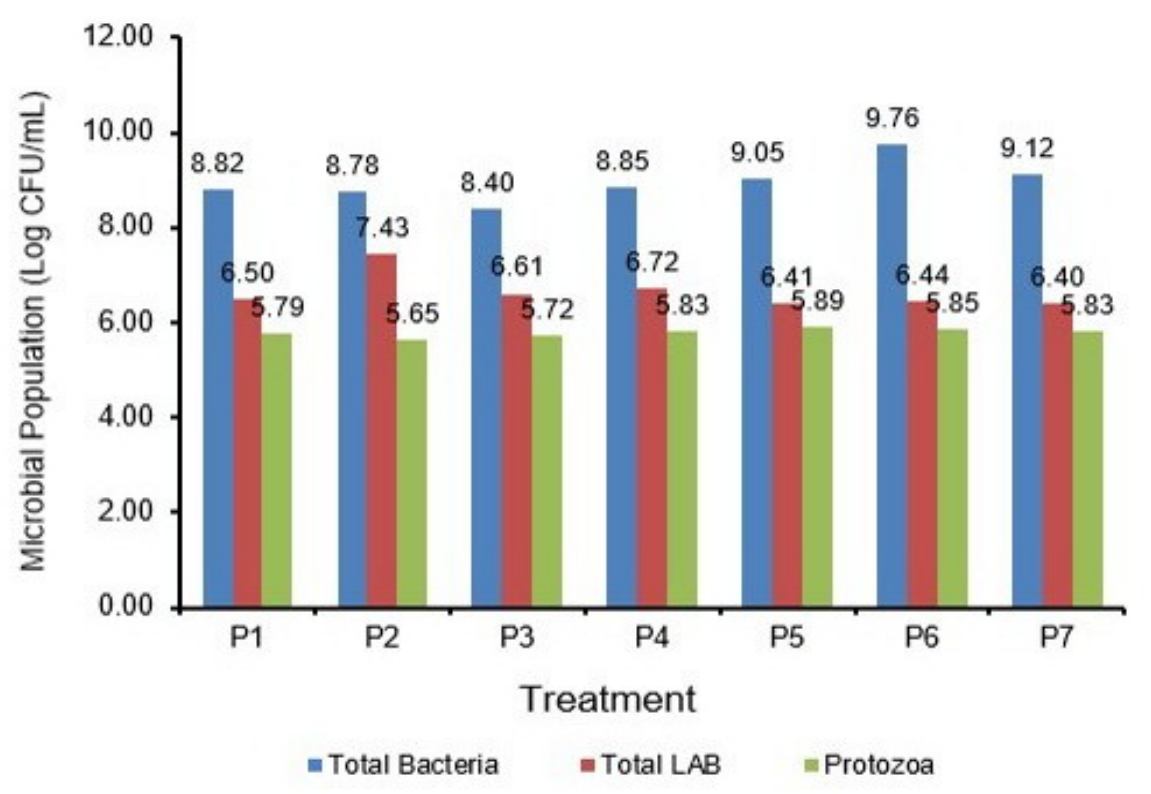

Figure 3. The Comparison among Total Bacteria, Total Lactic Acid Bacteria and Protozoa in Each Treatment $. \mathrm{P} 1=20 \%$ Pennisetum purpureum: $80 \%$ concentrate; $\mathrm{P} 2=30 \%$ P.purpureum: $70 \%$ concentrate; $\mathrm{P} 3=40 \%$ P.purpureum : $60 \%$ concentrate; $\mathrm{P} 4=50 \%$ P.purpureum: $50 \%$ concentrate; $\mathrm{P} 5=$ 20\% concentrate: $80 \%$ P.purpureum; P6 $=30 \%$ concentrate: $70 \%$ P.purpureum; P7 $=40 \%$ concentrate: $60 \%$ P.purpureum

protozoa were counted as described by Veira et al. (1983) using a Fuchs-Rosenthal counting chamber. Duplicate preparations of each sample were counted, and if either value differed from the average by more than $5 \%$, the counts were repeated. After being incubated for 24 hours, protozoa can be observed by using microscope at 200x magnification

\section{Statistical analysis}

The experiment design was a block randomized. The statistical analysis of data was performed using SPSS 16 for Windows. The difference among groups was determined by oneway ANOVA analysis. The Duncan's Multiple Range Test, one of the multiple comparison tests, was used when the difference among groups was found to be significant. Significance was defined at $\mathrm{P}<0.05$. Mocrobial diversity data were analyzed descriptively.

\section{RESULTS AND DISCUSSIONS}

\section{Chemical and pH analysis}

Chemical analysis of feed material is very important to evaluate the nutrient content of feed. Proximate analysis is one of parameter to determine the quality of feed material. The nutrition composition of feed material that used in this study is shown in Table 1.

The $\mathrm{pH}$ rumen indicate rumen conditions that are appropriate or inappropriate for the growth of rumen microbes. This study showed that the use of different levels of fermented concentrate did not affect the $\mathrm{pH}$ of rumen (Figure 1). The same $\mathrm{pH}$ values as control showed that the use of different levels of fermented concentrate does not interfere rumen fermentation activity. According to Dehority (2004), the rumen's normal $\mathrm{pH}$ is about 5.5-7.0. The $\mathrm{pH}$ value actually represents the amount of acid produced by microbial activity in the rumen (Elghandour et al., 2015; Hutton et al., 2012). The lowest $\mathrm{pH}$ value is generally achieved about 2-6 hours after meals, in accordance with the maximum acid production. Changes in $\mathrm{pH}$ are affected by time after meal, lactic acid supply, feed properties, and feeding frequency of animal. (Dehority, 2004; Seo et al. 2010).

\section{In vitro Incubation and Gas Production}

Total gas production for 48 hours incubation is presented in Table 2. The gas production comes from direct substrate fermentation $\left(\mathrm{CO}_{2}\right.$ and $\left.\mathrm{CH}_{4}\right)$ 
Table 3. Production of VFA and $\mathrm{NH}_{3}$ during $48 \mathrm{~h}$ Incubation

\begin{tabular}{cccccccc}
\hline \multirow{2}{*}{ Variable } & \multicolumn{7}{c}{ Treatment } \\
\cline { 2 - 7 } & P1 & P2 & P3 & P4 & P5 & P6 & P7 \\
\hline $\mathrm{C}_{2}$ & $44.51^{\mathrm{a}}$ & $41.38^{\mathrm{a}}$ & $42.94^{\mathrm{a}}$ & $43.86^{\mathrm{a}}$ & $39.48^{\mathrm{a}}$ & $43.65^{\mathrm{a}}$ & $47.43^{\mathrm{b}}$ \\
$\mathrm{C}_{3}$ & $30.17^{\mathrm{b}}$ & $31.40^{\mathrm{b}}$ & $31.89^{\mathrm{b}}$ & 27.84 & 21.57 & 23.99 & 24.46 \\
$\mathrm{C}_{4}$ & $13.45^{\mathrm{a}}$ & $14.71^{\mathrm{a}}$ & $13.73^{\mathrm{a}}$ & $16.28^{\mathrm{ab}}$ & $19.62^{\mathrm{ab}}$ & $16.64^{\mathrm{ab}}$ & $12.73^{\mathrm{a}}$ \\
$\mathrm{Iso}^{\mathrm{C}} \mathrm{C}_{4}$ & $5.26^{\mathrm{a}}$ & $7.08^{\mathrm{a}}$ & $5.56^{\mathrm{a}}$ & $5.87^{\mathrm{a}}$ & $13.11^{\mathrm{ab}}$ & $9.33^{\mathrm{a}}$ & $7.95^{\mathrm{a}}$ \\
$\mathrm{C}_{5}$ & $2.5^{\mathrm{a}}$ & $1.27^{\mathrm{a}}$ & $1.59^{\mathrm{a}}$ & $1.82^{\mathrm{a}}$ & $1.53^{\mathrm{a}}$ & $2.16^{\mathrm{a}}$ & $3.26^{\mathrm{ab}}$ \\
$\mathrm{Iso} \mathrm{C}_{5}$ & $4.11^{\mathrm{a}}$ & $4.16^{\mathrm{a}}$ & $4.29^{\mathrm{a}}$ & $4.33^{\mathrm{a}}$ & $4.69^{\mathrm{a}}$ & $4.23^{\mathrm{a}}$ & $4.17^{\mathrm{a}}$ \\
$\mathrm{C}_{2} / \mathrm{C}_{3}$ & $1.47^{\mathrm{a}}$ & $1.31^{\mathrm{a}}$ & $1.35^{\mathrm{a}}$ & $1.58^{\mathrm{a}}$ & $1.83^{\mathrm{a}}$ & $1.82^{\mathrm{a}}$ & $1.94^{\mathrm{a}}$ \\
$\mathrm{NH}_{3}$ & $6.09^{\mathrm{bc}}$ & $6.59^{\mathrm{c}}$ & $6.39^{\mathrm{c}}$ & $6.94^{\mathrm{c}}$ & $4.98^{\mathrm{b}}$ & $5.00^{\mathrm{b}}$ & $4.80^{\mathrm{b}}$ \\
\hline
\end{tabular}

$\mathrm{P} 1=20 \%$ Pennisetum purpureum: $80 \%$ concentrate; P2 $=30 \%$ P.purpureum: $70 \%$ concentrate; $\mathrm{P} 3=40 \%$ P.purpureum : 60\% concentrate; P4 = 50\% P.purpureum: 50\% concentrate; P5 $=20 \%$ concentrate: $80 \%$ P.purpureum; P6 $=30 \%$ concentrate: $70 \%$ P.purpureum; P7 $=40 \%$ concentrate: $60 \%$ P.purpureum; a-eDifferent superscripts within the same column are significantly different at $\mathrm{P}<0.05$.

and indirect gas production $\left(\mathrm{CO}_{2}\right)$ reactions from organic acids with bicarbonate buffers (Goel et al., 2008; McDonald et al. 2010; Hook et al., 2010). In addition, according to McDonald et al. (2010) gas composition in the rumen is consist of $40 \%$ carbon dioxide $\left(\mathrm{CO}_{2}\right), 30-40 \%$ methane $\left(\mathrm{CH}_{4}\right), 5 \%$ hydrogen, and a small portion of oxygen and nitrogen. Based on 24 hours incubation presented in Table 2, it was showed that the average of gas production was over $75 \%$ of the total gas during 48 hours incubation, this result is coherent with Jayanegara et al. (2009), which stated that more than $75 \%$ of the gas is generated after 24 hours of incubation period. Differences in gas production between treatments can be caused by rumen fluids, incubation conditions, and also substrates. Table 2 showed that the rate of gas production of each treatment decreased every hour in accordance with the reduced amount of substrate that can be fermented during the incubation period. Therefore, the rate of gas production will demonstrate the time required for rumen microorganisms to digest the entire substrate.

Figure 2 showed that the gas was still being produced until 48 hours of incubation time. This means that the tested substrate remained until the 48 hours of incubation. Consequently, the zero point of gas production could not be known. It takes up to 96 hours to obtain an accurate kinetic coefficient (Jayanegara et al., 2009) because incubation for 96 hours the substrate will be exhausted. If the substrate has been fermented out, then the zero point of the gas production rate will be known and the shape of the graph will be constant by forming horizontally as in the blank (Figure 2).

\section{Microbiology Analysis}

In this study, it was showed in the Figure 3 that the treatment of P1, P2, P3, and P4 had higher amounts of lactic acid bacteria than other treatments. In contrast, the total number of bacteria on treatment P1, P2, P3, and P4 was decreased. We assumed that L.plantarum TSD 10 has an antimicrobial ability that can inhibit the presence of pathogenic bacteria in the rumen thus affecting the reduction of total bacteria in the rumen. Fermentation with with $L$. plantarum might prevent harmful microbe in the digestive tract and increase the immune enhancing activity of fermented products (Rizzello et al., 2013; Ashraf and Shah., 2014; Fu et al., 2014; Li et al., 2012).

In addition, concentrate which is fermented by lactic acid bacteria not only as a preservation, but also as probiotic, therefore animals can obtain both nutrients and the probiotics from fermented feed (Sánchez et al., 2015; Hu et al., 2015). Ellis et al. (2016) found that the viable cells of lactic 
Table 4. Dry Matter Digestibility (DMD) and Organic Matter Digestibility (OMD) In vitro

\begin{tabular}{ccc}
\hline Treatment & DMD (\%) & OMD (\%) \\
\hline P1 & $65.80 \pm 1.32^{\mathrm{cd}}$ & $66.48 \pm 1.53^{\mathrm{b}}$ \\
P2 & $71.63 \pm 2.73^{\mathrm{d}}$ & $76.42 \pm 2.39^{\mathrm{c}}$ \\
P3 & $71.06 \pm 3.69^{\mathrm{d}}$ & $71.65 \pm 3.93^{\mathrm{c}}$ \\
P4 & $60.36 \pm 2.94^{\mathrm{bc}}$ & $60.76 \pm 4.52^{\mathrm{b}}$ \\
P5 & $50.89 \pm 3.49^{\mathrm{a}}$ & $59.28 \pm 1.75^{\mathrm{b}}$ \\
P6 & $55.07 \pm 5.81^{\mathrm{ab}}$ & $45.49 \pm 5.75^{\mathrm{a}}$ \\
P7 & $50.03 \pm 1.59^{\mathrm{a}}$ & $46.93 \pm 4.54^{\mathrm{a}}$ \\
\hline
\end{tabular}

$\mathrm{P} 1=20 \%$ Pennisetum purpureum: $80 \%$ concentrate; $\mathrm{P} 2=30 \%$ P.purpureum: $70 \%$ concentrate; $\mathrm{P} 3=40 \%$ P.purpureum : $60 \%$ concentrate; P4 $=50 \%$ P.purpureum: 50\% concentrate; P5 = 20\% concentrate: 80\% P.purpureum; P6 $=30 \%$ concentrate: $70 \%$ P.purpureum; $\mathrm{P} 7=40 \%$ concentrate: $60 \%$ P.purpureum; a-eDifferent superscripts within the same column are significantly different at $\mathrm{P}<0.05$.

acid bacteria in silage can play a role as probiotic in the rumen during fermentation process. Sari et al. (2017) also reported that lactic acid bacteria has an important role for producing lactic acid, which results in quicker drop of $\mathrm{pH}$. This finding suggested that L. plantarum population in fermented concentrate was sufficiently established during fermentation process and able to utilize the high concentration of $\mathrm{NH}_{3}-\mathrm{N}$. The $\mathrm{NH}_{3}-\mathrm{N}$ in the fermented concentrate was used as a source of $\mathrm{N}$ for microbial protein synthesis and for microbial growth (Calsamiglia et al., 2010; Belanche et al., 2012b).

The population of ciliated protozoa is more dominant in the rumen, while the population of flagellated protozoa is minor (Dehority, 2004). In this study the protozoa population presented in Figure 3 in the treatment of P4, P5, P6, and P7 were higher among other treatments. This is because the presence of protozoa naturally develops in the rumen to assist digestion of nutrients from forage crops containing high crude fiber (Noziere et al., 2011). However, the impact of protozoa on the rumen digestion depends on their concentration and the generic composition of their population (Belanche et al., 2012a).

\section{$\mathrm{NH}_{3}$ and VFA Production}

Ammonia is an important component for the synthesis of amino acids and microbial cell proteins. Protein from feed will be degraded by proteolytic bacteria with the help of protease enzyme into peptide then hydrolyzed to amino acid, and amino acid will go through deamination process to become ammonia. McDonald et al. (2010) states that ammonia is produced in conjunction with several small peptides and free amino acids, then it is utilized by rumen organisms for microbial protein synthesis. In addition, some of the amino acids will be further digested into organic acids, ammonia $\left(\mathrm{NH}_{3}\right)$, and carbon dioxide $\left(\mathrm{CO}_{2}\right)$.

The results of the average concentration of $\mathrm{NH}_{3}$ are presented in Table 3. This study showed that proportion of fermented concentrate can increase the production of $\mathrm{NH}_{3}$ in the treatment of $\mathrm{P} 2, \mathrm{P} 3$ and $\mathrm{P} 4$, while in the treatment of P5, P6, and $\mathrm{P} 7$ the amount of $\mathrm{NH}_{3}$ decreases. This is due to the tendency of increasing bacterial population in the treatment of P5, P6, and P7 (Figure 3) will reduce the value of $\mathrm{NH}_{3}$ concentration due to $\mathrm{NH}_{3}$ is an important source of $\mathrm{N}$ for rumen microbes for the microbial synthesis process.

Production of VFA after incubation for 48 hours is presented in Table 3. The use of feed which is dominated by fermented concentrate such as P1, P2, and P3 had significant effect $(\mathrm{P}<0.05)$ on propionic acid formation. In contrast, the use of feed which is dominated by forage on treatment $\mathrm{P} 7$ had significant effect $(\mathrm{P}<0.05)$ on acetate production.

$\mathrm{C}_{2} / \mathrm{C}_{3}$ ratio shows a pattern of microbial fermentation in the rumen that has the potential to form acetic acid or propionate. The lowest $\mathrm{C}_{2} / \mathrm{C}_{3}$ ratio is produced by $\mathrm{P} 2$ as shown in Table 3, an be explained that in this treatment has a higher fermentable organic content than others with $76.42 \%$ of IVOMD (Table. 4). The low of $\mathrm{C}_{2} / \mathrm{C}_{3}$ ratio is due to the high amount of fermentable organic matter enabling the formation of higher propionic acid than acetic acid. As reported by Moran (2005) that the fermentative digestion of carbohydrates especially starch will produce lactic acid, this lactic acid will be converted to propionic acid by microbial lactate utilization, such as Propionibacteria $s p$, Veillonella alkalescens and Peptostreptococcus elsdeini. The low of $\mathrm{C}_{2} / \mathrm{C}_{3}$ ratio will stimulate fattening and tend to body fat formation. In the treatment of P5, $\mathrm{P} 6$, and $\mathrm{P} 7$ showed higher $\mathrm{C}_{2} / \mathrm{C}_{3}$ ratio values than other treatments, this indicates that the microbial 
fermentation pattern leads to the formation of acetic acid because the carbohydrates contained in the feed are still dominated by fibrous carbohydrates and microbes that grow well are cellulolytic and hemicelulolytics microbes.

\section{Dry Matter Digestibility (DMD) and Organic Matter Digestibility (OMD)}

The results of DMD and OMD during 48 hours incubation for all treatments are presented in Table 4. Dry matter digestibility value is one of indication for feed quality, the higher digestibility value, the more nutrition will be absorbed by the body.

Based on DMD value it was found that $\mathrm{P} 2$ and $\mathrm{P} 3$ resulted the highest percentage of DMD with 71.63 and 71.06 respectively. It also has a similarity in OMD pattern, that $\mathrm{P} 2$ and $\mathrm{P} 3$ resulted the highest percentage of OMD with 76.42 dan 71.65 respectively. This study found that digestibility is affected by the presence of protozoa. The lower protozoa population, the higher digestibility value will be generated. This is because protozoa will consume fibrolytic bacteria so that the population will be less and will affect the process of feed degradation in the rumen. This is evidenced by the number of protozoa in the treatment of $\mathrm{P} 2$ and $\mathrm{P} 3$ is less than other treatments (Figure 3). In Table 4. It is showed that the increase of DMD value will increase the OMD value. This is in accordance with as reported by Muhtarudin and Liman (2006), that the dry matter digestibility will be in line with the organic matter digestibility value. Digestibility can also be affected by components in the feed. As reported by De Boever et al. (2005) that the structural components of plant feed material such as cellulose, lignin, cell wall, NDF and ADF will reduce the nutrient digestibility of feed, whereas soluble carbohydrates (starch) and crude protein can increase the nutrient digestibility.

\section{CONCLUSION}

Based on this study it could be concluded that fermented concentrate with the range proportion from $60-70 \%$ (P2 and P3) can be used for feed, particularly in beef cattle. In addition, characteristic of fermented concentrate can improve the digestibility of feed in the rumen metabolism.

\section{ACKNOWLEDGMENTS}

This research was funded by Unggulan-LIPI DIPA Grant for Food Security and Drug's Discovery of the Research Center for Biotechnology, Indonesian Institute of Sciences (2015-2017). In addition, the authors would like to thank the Center of Excellence of Biotechnology Animal of Beef Cattle and Dairy Cattle (PUI Kemenristekdikti 2018) for supporting this publication.

\section{REFERENCES}

Ahmed, S.T., Mun, H.S., Islam, M., M., Ko, S.Y., Yang, C.J. 2016. Effects of dietary natural and fermented herb combination on growth performance, carcass traits and meat quality in grower-finisher pigs. Meat Sci, $122: 7-15$.

AOAC. 2005. Official Methods of Analysis. 18th edition. AOAC International, Arlington, VA, USA

Ashraf, R. and N. P. Shah. 2014. Immune system stimulation by probiotic microorganisms. Critical reviews in Food Science and Nutrition. 54(7):938-956.

Belanche, A., G. delaFuente, J.M. Moorby and C.J. Newbold. 2012a. Bacterial protein degradation by different rumen protozoal groups. J.Anim.Sci. 90:4495-4504

Belanche, A., M. Doreau, J.E. Edwards, J.M. Moorby, E. Pinloche and C.J. Newbold. 2012b. Shifts in the rumen microbiota due to the type of carbohydrate and level of protein ingested by dairy cattle areas sociated with changes in rumen fermentation. J.Nutr. 142:1684-1692.

Calsamiglia, S., A. Ferret, C. Reynolds, N. Kristensen and A. Van Vuuren. 2010. Strategies for optimizing nitrogen use by ruminants. Animal. 4(7) : 1184-1196.

Canibe, N and B.B. Jensen. 2012. Fermented liquid feed-Microbial and nutritional aspects and impact on enteric diseases in pigs. Anim. Feed Sci. Technol. 173:17-40.

Cao, F. L., X.H. Zhang, W.W. Yu, L.G. Zhaoand T. Wang. 2012. Effect of feeding fermented Ginkgo biloba leaves on growth performance, meat quality, and lipid metabolism in broilers. Poult. Sci. 91: 1210-1221.

Cappuccino, J.G and N. Sherman. 2001. Microbiology: A Laboratory Manual. 6th 
Edition, Benjamin Cummings, San Francisco.

De Boever, J.L., J.M. Aerts, J.M.Vanacker and D.L. De Brabander. 2005. Evaluation of the nutritive value of maize silages using a gas production technique. Anim. Feed Sci. Technol. 123-124: 255-265.

Dehority, B. A and P. A. Tirabasso. 2004. Effect of feeding frequency on bacterial and fungal concentration, $\mathrm{pH}$, and other parameters in the rumen. J. Anim. Sci. $79: 2908$ - 2912.

Dei, H. K., S.P. Rose, A.M. Mackenzie and R. Amarowicz. 2008. Growth performance of broiler chickens fed diets containing shea nut (Vitellaria paradoxa, Gaertn.) meal fermented with Aspergillus niger. Poult. Sci. 87:1773-1778.

Elghandour M M, A.Z. Salem, J.S.M. Castañeda, L.M. Camacho, A.E. Kholif and J.C.V. Chagoyán. 2015. Direct-fed microbes: A tool for improving the utilization of low quality roughages in ruminants. Journal of Integrative Agriculture. 14:526-533.

Ellis, J. L., A. Bannink, I. K. Hindrichsen, R. D. Kinley and W. F. Pellikaan. 2016. The effect of lactic acid bacteria included as a probiotic or silage inoculant on in vitro rumen digestibility, total gas, and methane production. Anim. Feed Sci. Technol. 211: 61-74.

Fu, R., R. Chen., Y. Huang, H. Zhao and H. Li H., 2014. Effects of fermentated protein feed on the antioxidant ability and immune ability of growing-finishing pigs. Modern. J. Anim. Husbandry Vet. Med. 2:21-24.

Goel, G., H.P.S. Makkar and K. Becker. 2008. Effects of Sesbania Sesban and Carduus Pycnocephalus leaves and fenugreek (Trigonella Foenum-Graecum 1.) seeds and their extracts on partitioning of nutrients from roughage- and concentratebased feeds to methane. Anim. Feed Sci. Tech. 147:7289.

Goering, H. K and P. J. Van Soest. 1970. Forage Fiber Analyses (Apparatus, Reagents, Procedures, and Some Applications). Agriculture handbook no. 379, Agriculture Research Service USDA. Washington (DC), USA.

Hook, S.E., Wright, A.D.G., McBride, B.W. 2010. Methanogens: methane producers of the rumen and mitigation strategies. Archaea : 945785.

Humer, E., W. Wetscherek, C. Schwarz, and K.
Schedle. 2013. Effect of maize conservation technique and phytase supplementation on total tract apparentdigestibility of phosphorus, calcium, ash, dry matter, organic matter and crude protein in growing pigs. Anim. Feed Sci. Technol. 185:70-77.

Hungate, R. E. 1969. A Roll Tube Method for Cultivation of Strict Anaerobes. Academic Press. London.

Hutton, P G, Z. Durmic, E.L. Ghisalberti, G.R. Flematti,, R.M. Duncan, C.F. Carson and T.V. Riley. 2012. Inhibition of ruminal bacteria involved in lactic acid metabolism by extracts from Australian plants. Anim. Feed Sci. Technol. 176:170-177.

Jayanegara, A., A. Sofyan, H.P.S. Makkar and K. Becker .2009. Kinetika produksi gas, kecernaan bahan organik dan produksi gas metana in vitro pada hay dan jerami yang disuplementasi hijauan mengandung tanin. Med Pet. 32(2):120-129.

Kobashi Y., H. Ohmori, K. Tajima, T. Kawashima and H.Uchiyama. 2008. Reduction of chlortetracycline-resistant Escherichia coli in weaned piglets fed fermented liquid feed. Anaerobe 14: 201-204.

Lee, Y. L., J.H. Yang and J.L. Mau. 2008. Antioxidant properties of water extracts from Monascus fermented soybeans. Food Chem. 106:1128-1137.

Li, G., P.J. Brown, J.X. Tang, J. Xu, E.M. Quardokus, C, Fuqua and Y.V. Brun. 2012. Surface contact stimulates the just-in-time deployment of bacterial adhesins. Mol. Microbiol. 83:41-51.

McDonald P., R. Edwards and J. Greenhalgh. 2010. Animal Nutrition. 7th Edition. Ashford Colour Press. New York.

Moran, J. 2005. Tropical Dairy Farming. Landlinks Press. Australia.

Muhtarudin and Liman. 2006. Penentuan tingkat penggunaan mineral organik untuk memperbaiki bioproses rumen pada kambing secara in vitro. JIPI. 8(2):132-140.

Ng, C. C., C.Y. Wang, Y.P. Wang, W.S. Tzeng and Y.T. Shyu. 2011. Lactic acid bacterial fermentation on the production of functional antioxidant herbal Anoectochilus formosanus Hayata. J. Biosci. Bioengineer. 111:289-293.

Niba, A. T., J. D. Beal, A. C. Kudi and P. H. Brooks. 2009. Potential of bacterial fermentation as a biosafe method of 
improving feeds for pigs and poultry. Afr. J. Biotechnol. 8(9):1758-176.

Niba, A.T., H. Kouchika, A.C. Kudi, J.D. Beal, P.H. Brooks. 2008. Effect of particle size and micro-organism on lactic acid fermentation of sorghum, In: BSAS (Ed.), Proceedings of the British Society of Animal Science, Cambridge University Press, Scarborough, U. K., p. 43.

Noziere,P., F. Glasser and D. Sauvant. 2011. Invivo production and molar percentages of volatile fatty acids in the rumen : a quantitative review by an empirical approach. Animal. 5(3):403-414.

Ogimoto, K and S. Imal. 1987 . Atlas of Rumen Microbiology. Japan Scientific Societies Press, Tokyo.

Ørskov, E. R. and I. McDonald. 1979. The estimation of protein degradability in the rumen from incubation measurements weighted according to rate of passage. J. Agric. Sci. 92: 499-503.

Reale, A., L. Mannina, P. Tremonte, A.P. Sobolev, M.Succi, E. Sorrentino and R. Coppola. 2004. Phytate degradation by lactic acid bacteria and yeasts during the wholemeal dough fermentation: a 31P NMR study. J. Agric. Food Chem 52:6300-6305.

Rizzello, C. G., R. Coda, D.S. Macías, D. Pinto, B. Marzani, P. Filannino and M. Gobbetti. 2013. Lactic acid fermentation as a tool to enhance the functional features of
Echinacea spp. Microbial Cell Factories. 12: 44

Sánchez, B., M. Gueimonde, A.S. Peña and D. Bernardo. 2015. Intestinal microbiota as modulators of the immune system. J. Immunol. Res. Article ID. 159094.

Sari, N.F., R. Ridwan and Y. Widyastuti. 2017. The quality of corn silage product from technopark of Banyumulek Lombok, West Nusa Tenggara. Buletin Peternakan. 41(2):156-162.

Seo, J. K, S.W. Kim, M.H. Kim, S.D. Upadhaya, D.K. Kam and J.K. Ha. 2010. Direct-fed microbials for ruminant animals. AsianAustralas. J. Anim Sci. 23:1657-1667.

Theodorou, M. K., B. A. Williams, M. S. Dhanoa, A. B. McAllan and J. France. 1994. A simple gas production method using a pressure transducer to determine the fermentation kinetics of ruminant feeds. Anim. Feed Sci. Technol. 48:185-197.

Veira, D.M., M. Ivan and P.J. Jui. 1983. Rumen ciliate protozoa: effects on digestion in the stomach of sheep. J. Dairy Sci. 66:10151022.

Xin-Xu, H. U. 2015. Effects of complex probiotics fermented feed without antibiotic on growth performance,plasma biochemical parameters,immune function and meat quality in growing-finishing pig. J. Huazhong Agric. Univer. 1:72-77. 